\begin{tabular}{|c|c|} 
Kredo 4 (2020) \\
KREDO: Jurnal Ilmiah Bahasa dan Sastra \\
Terakreditasi Sinta 4 berdasarkan Keputusan Direktorat \\
Jenderal Penguatan Riset dan Pengembangan, \\
Kementerian Riset, Teknologi dan Pendidikan Tinggi \\
Republik Indonesia \\
Nomor: 23/E/KPT/2019. 08 Agustus 2019 \\
https://jurnal.umk.ac.id/index.php/kredo/index
\end{tabular}

\title{
PENGARUH METODE COPY THE MASTER TERHADAP KEMAMPUAN MENULIS CERPEN BERBENTUKAN WAG PADA SISWA KELAS XI SMA NEGERI 3 KOTA SUKABUMI
}

\author{
Neng Madu Ila Septeria ${ }^{1}$, Deden Ahmad Supendi ${ }^{2}$, David Setiadi ${ }^{3}$ \\ ilasepterianengmadu@gmail.com
}

Universitas Muhammadiyah Sukabumi, Indonesia

Info Artikel
Sejarah Artikel
Diterima
27 Juli 2020
Disetujui
1 Agustus 2020
Dipublikasikan
28 Oktober 2020
Keywords
Copy the master
learning method,
Write a short stories
Kata Kunci
Metode pembelajaran
copy the master,
Menulis cerpen

This study aims to determine whether there is an influence of the copy the master learning method on the ability of students in SMA Negeri 3 Sukabumi City, in writing short stories. The aspects assessed from the writings of the students include the elements of the short story builder. Subjects taken in this study consisted of only one class, namely class XI MIPA 1. The instruments - $\quad$ used in the study consisted of tests, documentation, and also observation sheets. Based on the results of the analysis of the data that has been done, it can be seen that, the ability to write short stories in grade XI MIPA 1 students in SMA Negeri 3 Sukabumi is not very good, if you look at the results of their pretest which is 64,21. After that, treatment is given in the form of learning methods copy the master, and then their writing skills are tested again. Can be seen an increase in the value of their posttest results to 82,17. But despite the increase, the value obtained is still not satisfactory, other than that after being tested for significance. The increase is not significant. So it can be concluded that the influence of the learning method exists, however, it is not too much. The most significant increase occurred in the element of building a short story that is the theme, setting, and character.

\begin{abstract}
Abstrak
Penelitian ini memiliki tujuan untuk mengetahui adakah pengaruh metode pembelajaran copy the master terhadap kemampuan peserta didik di sekolah SMA N 3 Kota Sukabumi, dalam menulis cerita pendek. Adapun aspek-aspek yang dinilai dari tulisan para peserta didik meliputi unsur pembangun cerita pendek. Subjek yang diambil dalam penelitian ini hanya terdiri satu kelas saja yaitu kelas XI MIPA 1. Instrument yang digunakan dalam penelitian terdiri dari tes, dokumentasi, dan juga lembar observasi. Berdasarkan pada hasil analisis data yang telah dilakukan, dapat diketahui bahwa, kemampuan menulis cerita pendek pada siswa kelas XI MIPA 1 di sekolah SMA Negeri 3 Kota Sukabumi tidaklah terlalu bagus, jika melihat kepada hasil pretest mereka yaitu 64,21 . Setelah itu diberikan treatment berupa metode pembelajaran copy the master, dan kemudian kemampuan menulis mereka diuji kembali. Dapat terlihat adanya peningkatan nilai pada hasil posttest mereka menjadi 82,17 Namun meskipun mengalami peningkatan, nilai yang didapatkan masih belum memuaskan, selain itu setelah diuji signifikansinya. Peningkatan tersebut tidaklah signifikan. Jadi dapat disimpulkan bahwa pengaruh dari metode pembelajaran itu ada namun, tidaklah terlalu banyak. Peningkatan yang paling banyak terjadi yaitu terletak pada unsur pembangun cerita pendek yakni tema, latar, dan tokoh.
\end{abstract}

\section{PENDAHULUAN}

$\begin{array}{ccc}\text { Empat } & \begin{array}{c}\text { komponen } \\ \text { berbahasa, }\end{array} & \text { yaitu }\end{array}$ keterampilan menyimak (listening skill), berbicara (speaking skill), membaca (reading skill), dan menulis (writing skill). Setiap keterampilan tersebut pada dasarnya adalah satu kesatuan dalam memegang peranan penting di berbagai kesempatan. Sebagai suatu keterampilan berbahasa, menulis adalah kegiatan yang

234 | Jurnal Kredo Vol. 4 No. 1 Oktober 2020 kompleks karena peserta didik dituntut untuk dapat menyusun dan mengorganisasikan isi tulisan serta menuangkannya dalam ragam bahasa tulis. Namun, kegiatan menulis tidak banyak diminati orang karena merasa tidak berbakat.

Dimyati 2013: 207-208) mengemukakan bahwa tujuan dari aspek keterampilan adalah sebagai kemampuan berkomunikasi, komunikasi non verbal, mengkoordinasikan dengan anggota 


Kredo 4 (2020)
KREDO: Jurnal Ilmiah Bahasa dan Sastra
Terakreditasi Sinta 4 berdasarkan Keputusan Direktorat
Jenderal Penguatan Riset dan Pengembangan,
Kementerian Riset, Teknologi dan Pendidikan Tinggi
Republik Indonesia
Nomor: 23/E/KPT/2019. 08 Agustus 2019
https://jurnal.umk.ac.id/index.php/kredo/index

tubuh, dan gerakan tubuh. Sedangkan menurut Sailo (2017) mengemukakan bahwa keterampilan menulis merupakan suatu keterampilan untuk memberikan pendapat dan juga suasana dengan tulisan.

Dibia (2017) mengemukakan bahwa kemampuan menulis dapat mengembangkan daya berfikir kritis dan juga mengungkapkan perasaan dan menulis juga merupakan suatu kegiatan yang kreatif karena dalam menulis dapat memilih kosa kata yang tepat sesuai ceritanya.

Kemampuan menulis bukanlah hal yang mudah oleh karena itu, menulis memerlukan minat untuk mengolah kata dan dijadikan suatu karangan yang indah. Maka dalam pembelajaran menulis atau mengarang pendidik harus mempunyai metode atau strategi dalam proses pembelajaran. Metode pembelajaran sangat diperlukan untuk menciptakan pembelajaran yang kreatif, menarik, dan menyenangkan. Peserta didik dalam pembelajaran menulis beranggapan bahwa menulis bukanlah hal yang menarik tetapi membosankan. Peserta didik merasa bosan karena peserta didik kesulitan untuk merangkai kata menjadi kalimat ataupun paragraf secara runtut dan padu (Puspitasari, 2016).

Menulis merupakan suatu proses inovatif yang menyalurkan gagasan dalam bentuk bahasa tulis misalnya memberitahu, menyakinkan, atau menghibur (Dalman, 2016: 3). Dari hasil proses inovatif disebut dengan istilah karangan atau tulisan. Menulis disebut juga mengarang suatu kegiatan yang menuntut beberapa kemampuan. Menulis merupakan aktivitas yang harus dilalui oleh peserta didik dalam proses belajar, terutama pada mata pelajaran bahasa dan sastra Indonesia. Kegiatan menulis ini diharapkan peserta didik dapat menyalurkan gagasan baik yang bersifat objektif maupun inovatif. Salah satu bentuk pembelajaran menulis dapat ditemukan pada materi tentang sastra.

Pembelajaran sastra di SMA berkaitan dengan pembelajaran menulis. Dengan begitu menulis dalam pembelajaran sastra merupakan keterampilan yang sangat sedikit dikuasai oleh peserta didik. Salah satunya kesulitan peserta didik dalam pembelajaran sastra dapat ditemukan dalam menulis cerpen.

Menurut Priyatni (2010: 126) cerpen merupakan bentuk karya fiksi. Cerita pendek sesuai dengan namannya yaitu melihatkan sifat yang serba pendek, baik peristiwa yang diungkapkan, isi cerita, jumlah kata yang digunakan, dan jumlah pelaku. Keterampilan menulis cerpen mengarahkan peserta didik agar memiliki kemampuan menyalurkan ide, gagasan pikiran, pengalaman, dan pendapatnya. Oleh karena itu, menulis cerpen sangat berhubungan erat dengan pengalaman sehari-hari. Bahwa pembelajaran menulis harus memiliki kemampuan memakai ejaan sebagai kaidah tata tulis.

Penelitian ini dilakukan dalam berbentukan WAG (whatsapp group) yang dimana hanya menggunakan aplikasi whatsapp tidak bisa dilakukan secara langsung atau bertatap muka. Karena adanya surat edaran nomor 4 tahun 2020 tentang pelaksanaan kebijakan pendidikan dalam masa darurat penyebaran corona virus disease (covid-19) yang semakin meningkat 


Kredo 4(2020)
KREDO: Jurnal Ilmiah Bahasa dan Sastra
Terakreditasi Sinta 4 berdasarkan Keputusan Direktorat
Jenderal Penguatan Riset dan Pengembangan,
Kementerian Riset, Teknologi dan Pendidikan Tinggi
Republik Indonesia
Nomor: 23/E/KPT/2019. 08 Agustus 2019
https://jurnal.umk.ac.id/index.php/kredo/index

maka kesehatan lahir dan batin siswa, guru, kepala sekolah, dan seluruh warga sekolah menjadi pertimbangan utama dalam pelaksanaan kebijakan pendidikan. Sehubung dengan hal tersebut maka pemerintah menyampaikan hal yang dimana proses belajar dari rumah melalui pembelajaran daring atau jarak jauh untuk memutus rantai penyebaran wabah corona (covid19).

Peneliti memilih menggunakan aplikasi whatsApp group karena sebagai media dalam pembelajaran dan sangat efektif dibandingkan dengan menggunakan aplikasi zoom atau lain sebagainya. Tidak melalui zoom bukan berarti tidak efektif tetapi akan sulitnya mendapatkan jaringan karena keberadaan rumahnya yang tidak memungkinkan.

Rabu, 12 februari 2020 di SMA Negeri 3 Kota Sukabumi, peneliti melaksanakan kegiatan magang masih banyak peserta didik belum mampu menyelesaikan latihan dalam menulis apalagi menulis sebuah cerpen. Penyebab rendahnya kemampuan menulis cerpen pada peserta didik yaitu penggunaan metode belajar yang dipakai pendidik tidak beraneka ragam, oleh karena itu peserta didik tidak memperoleh celah untuk menunjukkan kreativitasnya sehingga imajinasi sering tidak tersalurkan apabila pembelajaran yang berlangsung sangat membosankan.

Berdasarkan permasalahan di atas, peneliti memakai metode copy the master sebagai salah satu cara untuk memecahkan masalah peserta didik dalam menulis cerpen. Metode copy the master digunakan dengan cara meniru master yang diberikan kepada peserta didik. Master yang diberikan yaitu karya Asma Nadia dengan judul cerpen "cinta laki-laki biasa". Peniruan ini misalnya mengangkat temanya/ mencontoh alurnya/ mengadaptasi latarnya/ meminjam nama-nama tokohnya/ memiripkan konfliknya tidak meniru keseluruhan. Dengan cara tersebut pembelajaran menulis cerpen tidak akan menjadi sebuah beban melainkan kesenangan sehingga peserta didik mampu meningkatkan terhadap kemampuan menulis cerpen.

Penelitian sebelumnya yang pernah menggunakan metode Copy the Master dilakukan oleh Tri Utari (2018) dengan judul Pengaruh Metode Copy the Master Terhadap Kemampuan Menulis Cerita Legenda Pada Siswa Kelas VII SMP Negeri 1 Kuwarasan. Penelitian Utari dinilai berhasil karena kemampuan menulis cerita legenda dengan kelas eksperimen yang menggunakan metode Copy the Master hasilnya lebih tinggi jika dibandingkan dengan kelas kontrol tanpa menggunakan metode Copy the Master. Kelompok eksperimen dan kelompok kontrol sesudah melakukan pascates memiliki sesilis yaitu kelompok eksperimen 78,78 sedangkan, kelompok kontrol 67,16 yaitu memiliki selisih 11,62. Hal itu berarti kelompok eksperimen memiliki gain score yang lebih tinggi dan membuktikan bahwa metode Copy the Master yang dilakukan pada kelas eksperimen efektif digunakan dalam pembelajaran menulis cerita legenda.

Penelitian lainnya dilakukan oleh Mastini, Sarwiji Suwandi, dan Sumarwati (2016) dengan judul Peningkatan Keterampilan Menulis Cerpen Melalui Metode Pembelajaran 


Kredo 4 (2020)
KREDO: Jurnal Ilmiah Bahasa dan Sastra
Terakreditasi Sinta 4 berdasarkan Keputusan Direktorat
Jenderal Penguatan Riset dan Pengembangan,
Kementerian Riset, Teknologi dan Pendidikan Tinggi
Republik Indonesia
Nomor: 23/E/KPT/2019. 08 Agustus 2019
https://jurnal.umk.ac.id/index.php/kredo/index

Berbasis Pengalaman Dan Media Udiovisual Pada Siswa Kelas VII SMP Negeri 1 Juwana. Penelitian ini dinilai berhasil karena dalam setiap tes nya mengalami peningkatan. Terbukti dari perolehan nilai keterampilan menulis cerita pendek pada pratindakan yang sesuai KKM hanya 8 siswa (25\%) dengan nilai rata-rata 69,84. Pada perlakuan mengalami penin gkatan menjadi 21 siswa $(65,62 \%)$ yang sesuai dengan KKM dengan nilai rata-rata 78,12 . Dan pada test terakhir terdapat 27 siswa $(84,38 \%)$ yang tuntas dengan nilai rata-rata 81,56$)$.

\section{KAJIAN TEORI}

\section{A. Metode Pembelajaran Copy the Master}

Secara umum bahwa metode dapat diartikan sebagai cara melakukan sesuatu. Secara khusus, metode pembelajaran diartikan sebagai cara atau pola yang khas dalam memanfaatkan berbagai prinsip dasar pendidikan serta berbagai teknik dan sumberdaya terkait lainnya agar terjadi proses pembelajaran pada diri pembelajaran (Gintings, Abdorrakman. 2008: 42). Metode pembelajaran diartikan sebagai cara yang telah digunakan seorang pendidik, sehingga dalam menjalankan fungsinya, metode ialah alat untuk mencapai tujuan pembelajaran (Siregar, Evelin dan Hartini Nara, 2010: 80).Berdasarkan pendapat di atas mengenai metode pembelajaran adalah metode pembelajaran yang dilakukan secara teratur dan bertahap dengan cara yang berbeda-beda untuk mencap tujuan tertentu dibawah kondisi yang berbeda dan metode pembelajaran pun merupakan suatu cara yang dilakukan seorang pendidik untuk mencapai tujuan pembelajaran. Salah satu metode pembelajaran yang tepat digunakan dalam penelitian ini adalah metode copy the master.

Marahimin

(1994:

mengemukakan bahwa metode copy the master merupakan salah satu metode atau cara yang digunakan untuk meniru ahlinya atau master yang dihadirkan, yang dimaksud dengan meniru bukan meniru sama persis dengan master yang diberikan, akan tetapi cara, teknik, atau hanya metode yang ditiru.

Metode pembelajaran copy the master ini memiliki keuunggulan yaitu membantu menggugah imajinasi peserta didik dalam mengekspresikan pengalamannya, mengetahui contoh secara nyata dari master yang telah ditampilkan, pendidik merasa terbantu kaitannya dengan media pembelajaran, dan dapat dijadikan parameter bagi pemula karena master yang dihadirkan harus terjamin kualitasnya dan pernah dipublikasikan atau dibuat oleh seorang sastrawan yang ahli.

Untuk memudahkan menulis dengan menggunakan metode copy the master dalam pembelajaran menulis cerpen ada beberapa langkah yang dilakukan yaitu sebagai berikut.

1) Membaca dan memahami sebuah karya sastra.

2) Mampu membuat peserta didik senang membaca.

3) Pelajari karya sastra yang sudah dibaca tadi dengan seksama.

4) Buat analisis dan kerangkanya berdasarkan unsur-unsur intrinsik (tema, alur, latar, tokoh dan 


Kredo 4 (2020)
KREDO: Jurnal Ilmiah Bahasa dan Sastra
Terakreditasi Sinta 4 berdasarkan Keputusan Direktorat
Jenderal Penguatan Riset dan Pengembangan,
Kementerian Riset, Teknologi dan Pendidikan Tinggi
Republik Indonesia
Nomor: 23/E/KPT/2019. 08 Agustus 2019
https://jurnal.umk.ac.id/index.php/kredo/index

penokohan, gaya bahasa, dan sudut pandang).

Menurut Marahimin (1994: 11-12) mengemukakan bahwa salah satu metode yang mampu mendukung banyaknya latihan seseorang menulis adalah melalui copy the master karena metode ini mengharuskan peserta didik dalam latihan-latihan yang sesuai dengan master yang diberikan. Latihan dengan metode ini tidak diharuskan tulisan dari seorang master yang terkenal. Tetapi, dapat diambil dari sebuah tulisan yang berasal dari tulisan karya biasa setelah dilakukan modifikasi seperlunya. Kemudian model ini dianalisis terlebih dahulu, dilihat unsur-unsur dalam penulisan serta dilakukan hal-hal lain yang perlu, dan sesudah itu baru tiba waktunya untuk menulis. Tentu saja yang dituliskan itu tidak persis dengan modelnya. Jika sama persisnya dengan modelnya maka namanya menjiplak atau bahkan membajak. Sebenarnya yang akan di copy yaitu hanya idenya/ kerangkanya/ bahkan tekniknya. Mengubah tulisan dari suatu master yang di copy menjadi lain atau berbeda.

\section{B. Kriteria Pemilihan Master}

Marahimin

(1994:12)

mengemukakan bahwa menggunakan metode copy the master dalam pembelajaran menulis cerpen. Master yang perlu ditampilkan bukan hanya master yang biasa saja, melainkan ada beberapa kriteria yang perlu diperhatikan dalam memilih master yaitu sebagai berikut.

1) Master yang dipilih yaitu tulisan cerpen seorang penulis yang terkenal dalam menulis cerpen atau diambil dari sebuah tulisan berasal dari tulisan karya biasa yang dianggap sebagai sebuah model, setelah dilakukan modifikasi seperlunya. Kemudian model ini dianalisis terlebih dahulu, dilihat dari unsur-unsur sebuah penulisan, serta dilakukan hal yang perlu, sesudah itu dilakukannya untuk menulis.

2) Master dipilih yaitu karya seorang ahli yang sudah terkenal dan sudah sering didengar peserta didik sebagai teks cerpen pengarang terkenal dalam menulis teks cerpen.

3) Master dapat pula seorang sastrawan terkenal yang ahli dalam menulis teks cerpen.

Master yang dipilih harus sesuai dengan tingkat kemampuan peserta didik dalam menulis teks cerpen.

\section{Langkah-langkah Metode Copy the Master}

Menurut Marahimin (1994:11) telah menjelaskan langkah-langkah pembelajaran dengan menggunakan metode copy the master yaitu sebagai berikut.

1) Peserta didik membaca tulisan yang menjadi model.

2) Peserta didik melihat isi dan bentuk tulisan dari model yang disajikan.

3) Peserta didik menganalisis dan membuat kerangka tulisan sesuai dengan model.

Peserta didik latihan menulis dengan meng-copy kerangka, ide, atau teknik penulisan dari tulisan yang menjadi model.

\section{Pengertian Cerpen}

Cerita pendek (cerpen) merupakan karya sastra yang berbentuk prosa naratif. Prosa adalah bentuk karya sastra yang diuraikan menggunakan bahasa 


Kredo 4 (2020)
KREDO: Jurnal Ilmiah Bahasa dan Sastra
Terakreditasi Sinta 4 berdasarkan Keputusan Direktorat
Jenderal Penguatan Riset dan Pengembangan,
Kementerian Riset, Teknologi dan Pendidikan Tinggi
Republik Indonesia
Nomor: 23/E/KPT/2019. 08 Agustus 2019
https://jurnal.umk.ac.id/index.php/kredo/index

bebas atau panjang, tidak terikat oleh aturan-aturan seperti dalam puisi (Wicaksono, 2014:13). Fiksi atau prosa naratif ini terbagi atas tiga genre, yakni cerita pendek (cerpen), novelet (novel pendek), dan novel atau roman. Menulis cerpen yaitu bentuk apresiasi seorang penulis yang menyampaikan gagasan dan yang dipikirkannya.

Edgar Allan Poe (dalam Nurgiyantoro, 2010: 10) mengemukakan bahwa cerpen merupakan sebuah cerita yang selesai dibaca dalam sekali duduk, kira-kira berkisar antara setengah sampai dua jam, suatu hal yang kiranya tak mungkin dilakukan untuk sebuah novel.

Pengertian lainnya yang mengenai cerpen yaitu menurut Priyatni (2010: 126) bahwa cerpen merupakan salah satu bentuk karya fiksi. Cerita pendek sesuai dengan namanya memperlihatkan sifat yang serba pendek, baik peristiwa yang diungkapkan, isi cerita, jumlah kata yang digunakan, dan jumlah pelaku.

Berdasarkan pendapat di atas dapat disimpulkan bahwa cerpen merupakan karya sastra yang berbentuk prosa naratif. Cerpen pun merupakan bentuk karya fiksi. Menulis cerpen adalah bentuk dari apresiasi seorang penulis untuk menyampaikan gagasannya.

\section{E. Jenis-jenis Cerita Pendek}

Jenis-jenis cerpen ini telah dikemukakan oleh Nurgiyantoro (2013: 12) yang berdasarkan jumlah kata yang terdapat di dalam cerpen terbagi menjadi tiga jenis yaitu diantaranya Short Short Story, Midle Short Story, dan Long Short Story.

Berdasarkan pendapat di atas bahwa jenis cerpen tersebut terbagi menjadi 3 yaitu short short story, middle short story, dan long short story. Sedangkan dalam penelitian ini hanya menggunakan atau dalam jenis cerpen ini yang dipakai hanya satu yakni short short story.

\section{F. Ciri-ciri Cerita Pendek}

Ciri-ciri cerpen ini dikemukakan oleh Nurgiyantoro (2013: 14) bahwa cerpen memiliki ciri-ciri sebagai berikut:

1) Jumlah kata tidak melebihi dari sepulluh ribu kata.

2) Berplot tunggal; konflik yang dibangun dan klimaks yang diperoleh pun tunggal.

3) Tidak menggambarkan semua kisah para tokohnya. Hal ini dikarenakan dalam cerpen yang digambarkan hanyalah inti sarinya saja.

4) Pelukisan latar dalam cerpen hanya sebatas implisit atau secara garis besarnya saja.

5) Pemakaian kata yang sederhana, ekonomis, dan mudah dipahami oleh pembaca.

6) Jalan ceritanya lebih pendek dari novel dan novelet.

7) Tokoh dalam cerpen terbatas baik mengenai yang menyangkut jumlah maupun data-data jati diri tokoh khususnya perwatakan.

8) Kesan yang ditinggalkan dari cerpen tersebut sangat mendalam sehingga pembaca dapat ikut merasakan kisah dari cerita tersebut.

9) Cerpen yang baik harus memenuhi kriteria kepaduan.

Berdasarkan pemaparan ciri-ciri cerpen di atas selanjutnya yaitu struktur cerita pendek.

\section{G. Unsur Pembangun Cerita Pendek}

Menurut Aminuddin (2011: 90) bahwa cerpen merupakan salah satu jenis 


Kredo 4 (2020)
KREDO: Jurnal Ilmiah Bahasa dan Sastra
Terakreditasi Sinta 4 berdasarkan Keputusan Direktorat
Jenderal Penguatan Riset dan Pengembangan,
Kementerian Riset, Teknologi dan Pendidikan Tinggi
Republik Indonesia
Nomor: 23/E/KPT/2019. 08 Agustus 2019
https://jurnal.umk.ac.id/index.php/kredo/index

prosa fiksi yang memiliki unsur-unsur pembangun. Unsur-unsur yang ada di dalam cerpen mencakup unsur intrinsik, cerpen yang baik mengandung unsurunsurpembangun sebagai berikut:

1) Tema merupakan ide yang mendasari suatu cerita sehingga berperan juga sebagai pangkal tokoh pengarang dalam memaparkan karya fiksi yang diciptakan.

2) Alur merupakan peristiwa-peristiwa yang mempunyai penekanan pada hubungan kausalitas. Stanton (dalam Nurgiyantoro, 2013: 167) mengemukakan bahwa alur merupakan cerita yang berisi urutan kejadian, namun tiap kejadian itu hanya dihhubungkan secara sebab akibat, peristiwa yang satu disebabkan atau menyebabkan terjadinya peristiwa yang lain.

3) Dalam latar atau setting ini meliputi tempat, waktu, dan budaya yang digunakan dalam suatu cerita. Latar merupakan suatu cerita bisa bersifat factual atau bisa pula imajinatif. Maka cerpen dikatakan baik apabila tepat dalam memilih tempat yang mengukuhkan terjadinya peristiwa, tepat memilih waktu yang memiliki tampakan atmosfir dan mamppu menggambarkan suasana yang mendukung cerita.

4) Tokoh merupakan salah satu unsur yang penting dalam suatu novel atau cerita rekaan. Menurut Baldic (dalam Nurgiyantoro, 2013: 247) mengemukakan bahwa tokoh merupakan orang yang menjadi pelaku dalam cerita fiksi atau drama, sedangkan penokohan merupakan penghadiran tokoh dalam cerita fiksi atau drama dengan system langsung atau tidak langsung dan mengundang pembaca untuk menafsirkan kualitas dirinya lewat kata dan tindakannya.

5) Sudut pandang merupakan salah satu kaidah pengarang menampilkan tokoh-tokoh cerita dalam cerita yang dipaparkannya. Sudut pandang adalah pandangan yang dipergunakan pengarang sebagai sarana untuk menyajikan tokoh, tindakan, latar, dan berbagai peristiwa yang membentuk cerita dalam sebuah karya fiksi kepada pembaca. Hal ini dikemukakan menurut Abrams (dalam Nurgiyantoro, 2013: 338). Segala sesuatu yang dikemukakan dalam karya fiksi memang milik pengaranng, pandangan hidup, dan tafsirannya terhadap kehidupan.

6) Di dalam karya sastra bahwa kedudukan bahasa sangat penting karena itu bahasa tidak hanya digunakan sebagai sarana untuk mengungkapkan maksud dari cerita tersebut, tetapi tidak berfungsi sebagai sarana yang dapat menimbulkan kesan imajinatif terhadap pembacanya. Dalam sebuah cerpen bahwa gaya bahasa ini sangatlah emnarik untuk dipelajari. Oleh karena itu, gaya bahasa bisa menjadi suatu ciri khas tersendiri yang di mana menggambarkan kepribadian setiap penulisnya. Dalam gaya bahasa ini juga bahasa-bahasa indah yang dipakai atau digunakan dalam tulisan untuk meningkatkan nilai suatu karangan tersebut.

\section{METODE PENELITIAN}

Penelitian ini dilaksanakan di SMA Negeri 3 Kota Sukabumi Tahun 


Kredo 4 (2020)
KREDO: Jurnal Ilmiah Bahasa dan Sastra
Terakreditasi Sinta 4 berdasarkan Keputusan Direktorat
Jenderal Penguatan Riset dan Pengembangan,
Kementerian Riset, Teknologi dan Pendidikan Tinggi
Republik Indonesia
Nomor: 23/E/KPT/2019. 08 Agustus 2019
https://jurnal.umk.ac.id/index.php/kredo/index

Pelajaran 2019/2020, populasi dalam penelitian ini yaitu seluruh siswa kelas XI MIPA SMA Negeri 3 Kota Sukabmui sebanyak 285 siswa tersebar 8 kelas. Dilakukan dalam penarikan sampel yaitu tidak secara acak (purposive sampling). Dipurposive ini bukan siswanya, melainkan kelas yaitu kelas XI MIPA 1 sebagai sampel dengan jumlah 35 siswa. Penelitian ini peneliti menggunakan metode kuantitatif. Menggunakan desain eksperimen yang berbentuk one-group pretest-posttest desain. Teknik analisis data yang digunakan yaitu teknik deskriptif yang mendeskripsikan data untuk menguji hipotesis dengan cara membandingkan harga $\mathrm{t}_{\text {Hitung }}$ dan $\mathrm{t}_{\text {Tabel }}$. $\mathrm{t}_{\text {Hitung }}<\mathrm{t}_{\text {Tabel }}$ dengan ketentuan jika $\alpha=$ 0,05 maka $\mathrm{H}_{0}$ diterima dan $\mathrm{H}_{1}$ ditolak dengan pengertian tidak ada pengaruh metode copy the master terhadap kemampuan menulis cerpen pada siswa kelas XI SMA Negeri 3 Kota Sukabumi Tahun Pelajaran 2019/2020.

\section{HASIL DAN PEMBAHASAN}

Hasil penelitian yang telah dilakukan beserta pembahasannya mengenai pengaruh metode pembelajaran Copy the Master terhadap kemampuan menulis cerpen pada siswa kelas XI SMA Negeri 3 Kota Sukabumi tahun pelajaran 2019/2020.

Data hasil penelitiannya dijabarkan ke dalam empat bagian yaitu, profil sekolah, data hasil pretest, data hasil posttest, dan distribusi nilai hasil pretest dan posttest. Sementara pembahasannya akan diuraikan ke dalam tiga bagian sebagai yaitu pembahasan hasil pembelajaran, pembahasan hasil penelitian, dan uji hipotesis.
Tabel 1. Data Skor Penilaian Pretest

\begin{tabular}{|c|c|c|c|}
\hline Nilai & $\begin{array}{c}\text { Jumlah } \\
\text { Skor }\end{array}$ & $\begin{array}{c}\text { Tingkat } \\
\text { Penguasaan } \\
(\%)\end{array}$ & Keterangan \\
\hline $81-100$ & 2 & $5,7 \%$ & $\begin{array}{c}\text { Sangat } \\
\text { Baik }\end{array}$ \\
\hline $61-80$ & 16 & 45,8 & Baik \\
\hline $41-60$ & 17 & 48,5 & $\begin{array}{c}\text { Cukup } \\
\text { Baik }\end{array}$ \\
\hline $21-40$ & 0 & 0 & $\begin{array}{c}\text { Kurang } \\
\text { Baik }\end{array}$ \\
\hline $0-20$ & 0 & 0 & $\begin{array}{c}\text { Tidak } \\
\text { Baik }\end{array}$ \\
\hline Jumlah & 35 & 100 & \\
\hline
\end{tabular}

Berdasarkan tabel di atas didapatkan hasil pretest pada kemampuan menulis cerpen termasuk dengan kategori sangat baik sebanyak 2 orang atau 5,7\%, kategori baik sebanyak 16 orang atau $45,8 \%$, dan kategori cukup baik sebanyak 17 orang atau 48,5\%. Hasil pretest pada kemampuan menulis cerpen di atas dalam kategori tidak normal.

Hasil penelitian posttest, pendidik mengawali pelajaran dengan memberikan salam kepada peserta didik sebagai pembukaan, lalu mengabsen. Setelah itu pendidik memberikan apresiasi peserta didik dan menjelaskan pembelajaran yang dicapai. Kegiatan selanjutnya pendidik menjelaskan tentang metode copy the master dan peserta didik diberikan contoh cerpen dari seorang pengarang terkenal, peserta didik untuk membaca cerpen terlebih dahulu. Kemudian pendidik kembali menyuruh peserta didik menulis cerpen dengan meniru contoh cerpen yang sudah ada. Setelah pelajaran selesai kemudian pendidik menyimpulkan materi dan mengumpulkan hasil kerja peserta didik. 


\begin{tabular}{|c|c|} 
Kredo 4 (2020) \\
KREDO: Jurnal Ilmiah Bahasa dan Sastra \\
Terakreditasi Sinta 4 berdasarkan Keputusan Direktorat \\
Jenderal Penguatan Riset dan Pengembangan, \\
Kementerian Riset, Teknologi dan Pendidikan Tinggi \\
Republik Indonesia \\
Nomor: 23/E/KPT/2019. 08 Agustus 2019 \\
https://jurnal.umk.ac.id/index.php/kredo/index
\end{tabular}

Tabel 2. Data Skor Penilaian Postest

\begin{tabular}{|c|c|c|c|}
\hline Nilai & Jumlah Skor & $\begin{array}{c}\text { Tingkat } \\
\text { Penguasaan }(\%)\end{array}$ & Kriteria \\
\hline $81-100$ & 20 & 57,14 & Sangat Baik \\
\hline $61-80$ & 14 & 40 & Baik \\
\hline $41-60$ & 1 & 2,86 & Cukup Baik \\
\hline $21-40$ & 0 & 0 & $\begin{array}{c}\text { Kurang } \\
\text { Baik }\end{array}$ \\
\hline $0-20$ & 0 & 0 & Tidak Baik \\
\hline Jumlah & 35 & 100 & \\
\hline
\end{tabular}

Tabel di atas bahwa hasil posttest pada kemampuan menulis cerpen peserta didik dengan menggunakan metode copy the master termasuk kategori sangat baik sebanyak 20 orang atau 57,14\%, kategori baik sebanyak 14 orang atau $40 \%$, dan kategori cukup baik sebanyak 1 orang atau $2,86 \%$. Hasil posttest terhadap kemampuan menulis cerpen di atas dalam kategori normal dan wajar.

Pengaruh metode copy the master terhadap kemampuan menulis cerpen pada siswa kelas XI SMA Negeri 3 Kota Sukabumi Tahun Pelajaran 2019/2020 tidak memberikan pengaruh yang signifikansi, dengan nilai rata-rata yang diperoleh yaitu 82,17. Data ini termasuk dalam kategori sangat baik, sedangkan pembelajaran menulis cerpen sebelum menggunakan metode copy the master dengan nilai rata-rata 64,91 termasuk dalam kategori baik.

Hasil didapatkan dari data penelitian yang dinilai berdasarkan aspek yang terdapat dalam penilaian menulis cerpen yakni, tema, alur, latar, tokoh, dan sudut pandang. Rata-rata hasil menulis cerpen tersebut peserta didik tidak mampu menyatu padukan antar kalimat yang ada menjadi satu paragraph sehingga isi cerita menjadi kurang padat dan lengkap. Selain itu tidak digunakannya gaya penuturan yang jelas pada cerpen yang dibuat. Peserta didik banyak menggunakan bahasa sehari-hari mereka. Pretest yang unggul yakni pada tema dan latar, hal ini terlihat pada cerpen dengan judul "Dunia Seakan Milik Berdua". Dalam cerpen ini tema terlihat jelas dan latarnya pun jelas.

Untuk Posttest, penilaian menulis cerpen ungul paada aspek tema, alur, latar, tokoh, dan sudut pandang. Dapat kita lihat pada cerpen Dunia Seakan Milik Berdua", unsur pembangun pada cerita pendek jelas dan berkembang. Peserta didik lebih mampu menggunakan penokohan dengan jalan cerita yang padat sehingga cerita pendek berkesan tidak asal tulis. Sehingga tidak adanya pengaruh dalam menggunakan metode copy the master terhadap kemampuan menulis cerpen. Meskipun hasil pretest lebih kecil dari posttest atau ketika melaksanakan posttest nilai yang didapatkan meningkat. Dari data yang diperoleh oleh $\mathrm{t}_{\text {Hitung }}<\mathrm{t}_{\text {Tabel }}$ dengan $\mathrm{df}=$ $\mathrm{N}-1$, df $=35-1=34$ diperoleh taraf signikansi $0,05=1,69$. Karena $t_{\text {Hitung }}<$ $\mathrm{t}_{\text {Tabel }}$ yaitu $0,35<1,69$, maka hipotesis $\mathrm{H}_{0}$ diterima dan $\mathrm{H}_{1}$ ditolak. Sehingga metode pembelajaran copy the master tidak berpengaruh terhadap kemampuan menulis cerpen peserta didik.

\section{SIMPULAN}

Berdasarkan hasil penelitian yang telah didapatkan yang dihubungkan dnegan rumjusan masalah, maka dapat disimpulkan bahwa kemampuan menulis cerpen peserta didik sebelum menggunakan metode pembelajaran copy the master masih terbilang cukup dengan skor rata-rata 64,91 yang artinya peserta didik masih belum menguasai tata cara menulis sebuah karangan cerita pendek sesuai dengan unsur pembangun

242 | Jurnal Kredo

Vol. 4 No. 1 Oktober 2020 


\begin{tabular}{|c|c|} 
Kredo 4 (2020) \\
KREDO: Jurnal Ilmiah Bahasa dan Sastra \\
Terakreditasi Sinta 4 berdasarkan Keputusan Direktorat \\
Jenderal Penguatan Riset dan Pengembangan, \\
Kementerian Riset, Teknologi dan Pendidikan Tinggi \\
Republik Indonesia \\
Nomor: 23/E/KPT/2019. 08 Agustus 2019 \\
https://jurnal.umk.ac.id/index.php/kredo/index
\end{tabular}

cerita pendek yang tepat. Pada pelaksanaan pretest beberapa peserta didik masih keliru dalam unsur pembangun dalam cerita pendek yang digunakannya. Kemampuan menulis cerita pendek setelah menggunakan metode pembelajaran copy the master mengalami perubahan. Hal tersebut dapat terlihat dari perbedaan skor nilai rata-rata posttest. Jumlah nilai rata-rata posttest adalah 82,17 artinya peserta didik sudah emngalami peningkatan dalam menulis cerita sebuah karangan cerita pendek yang meniru dari masternya yaitu pada cerpen yang berjudul "cinta laki-laki biasa" karya Asma Nadia. Selain itu, peningkatan kemampuan menulis cerpen peserta didik dilihat dari perolehan gain sebesar 676. Perbedaan ini dikarenakan adanya pengaruh dari penggunaan metode pembelajaran copy the master. Hasil perhitungan rata-rata pada pretest dan posttest. Perolehan nilai pada posttest lebih besar daripada perolehan nilai pada kegiatan pretest. Hal tersebut ditunjukkan dengan nilai rata-rata posttest naik menjadi 82,17 . Tentunya hal ini menyebabkan peningkatan nilai dari pretest dan posttest, sehingga metode pembelajaran copy the master dapat membantu peserta didik dalam meningkatkan kemampuan menulis cerpen.

Berdasarkan hasil pengujian statistik Uji- $t$ pada data skor tes akhir, maka didapat $\mathrm{t}_{\text {hitung }}=0,35<\mathrm{t}_{\text {tabel }} 1,69$. Hasil uji hipotesis menyatakan bahwa $\mathrm{H}_{0}$ diterima karena $\mathrm{t}_{\text {hitung }}<\mathrm{t}_{\text {tabel }}$. Dengan kata lain, rata-rata hasil posttest lebih baik daripada rata-rata hasil pretetst. Namun setelah diuji signifikansinya, $t_{\text {hitung }}$ ternyata lebih kecil daripada $t_{\text {tabel }}$ sehingga kenaikan nilai tersebut tidak signifikan. Sehingga dapat disimpulkan bahwa metode pembelajaran copy the master tidak berpengaruh terhadap kemampuan menulis cerpen berbentukan $W A G$ pada siswa kelas XI MIPA 1 SMA Negeri 3 Kota Sukabumi.

\section{DAFTAR PUSTAKA}

Aminuddin. 2011. Pengantar Apresiasi Karya Sastra. Bandung: Sinar Baru Algensindo.

Dalman. 2016. Keterampilan Menulis. Jakarta: Rajawali Pers.

Dibia, I Ketut. 2017. "Pemberdayaan Teknik Bercerita Berbasis Budaya Bali Dalam Pembelajaran Keterampialn Menulis Karangan Pribadi Siswa Kelas V SD Mutiara Singaraja”. Journal Of Research and Evaluation. 1, 2, 113-119.

Dimyati dan Mudjiono. 2013. Belajar dan Pembelajaran. Jakarta: PT Rineka Cipta.

Gintings, Abdorrakhman. 2008. Belajar dan Pembelajaran. Bandung: Humaniora.

Marahimin, I. 1994. Menulis Secara Populer. Jakarta: Pustaka Jaya. 


Kredo 4 (2020)
KREDO: Jurnal Ilmiah Bahasa dan Sastra
Terakreditasi Sinta 4 berdasarkan Keputusan Direktorat
Jenderal Penguatan Riset dan Pengembangan,
Kementerian Riset, Teknologi dan Pendidikan Tinggi
Republik Indonesia
Nomor: 23/E/KPT/2019. 08 Agustus 2019
https://jurnal.umk.ac.id/index.php/kredo/index

Mastini, dkk. 2016. "Peningkatan Keterampilan Menulis Cerpen Melalui Metode Pembelajaran Berbasis Pengalaman Dan Media Udiovisual Pada Siswa Kelas VII SMP Negeri 1 Juwana”. Jurnal FKIP UNS. 1, (1), 30.

Nurgiyantoro, Burhan. 2010a. Menulis Secara Populer. Jakarta: Pustaka Jaya.

Nurgiyantoro, Burhan. 2013. Teori Pengkajian Fiksi. Yogyakarta: Gadjah Mada University Press.

Priyatni, Endah Tri. 2010. Membaca Sastra Dengan Rancangan Literasi Kritis. Jakarta: Budi Aksara.

Puspita, Sari. Enjang Supriatna. 2016. "Model Pembelajaran kontekstual Berbasis Pengalaman Dalam Pembelajaran Menulis Teks Anekdot Pada Kelas X SMA Negeri Bandung". Jurnal Ilmiah UPT P2M STKIP Siliwangi. 3, 1.

Sailo, Irawati. 2017. "Peningkatan Keterampilan Menulis Karangan Narasi Menggunakan Model Contextual Teaching and Learning Siswa Kelas IV'. Jurnal Pendidiakn Guru Sekolah Dasar. 5, 501.

Siregar, Eveline dan Hartin. 2010. Teori Belajar dan Pembelajaran. Bogor: Ghalia Indonesia.

Utari, Tri dkk. 2018. "Pengaruh Metode Copy the Master Terhadap Kemampuan Menulis Cerita Legenda Pada Siswa Kelas VII SMP Negeri 1 Kuwarasan”. Jurnal Pendidikan Bahasa dan Sastra Indonesia. 6, (50), 105-113.

Wicaksono, Andri. 2014. Pengkajian Prosa Fiksi. Yogyakarta: Garudhawacana. 